\title{
OCCURRENCE OF STORM-GENERATED BEDFORMS ALONG THE INNER CONTINENTAL SHELF - SOUTHEASTERN BRAZIL
}

\author{
Daphnne Moraes Costa Moscon ${ }^{1}$ and Alex Cardoso Bastos ${ }^{2}$ \\ ${ }^{1}$ Universidade Federal Fluminense - UFF \\ Instituto de Geociências \\ (Campus da Praia Vermelha, $4^{\circ}$ andar, 24210-346 Niterói, RJ, Brasil) \\ daphnnemoraes@igeo.uff.br \\ ${ }^{2}$ Universidade Federal do Espírito Santo - UFES \\ Departamento de Ecologia e Recursos Naturais \\ (29075-910 Vitória, ES, Brasil) \\ alex@dern.ufes.br
}

A B S TR A C T

Side-scan sonar surveys were carried out in two different areas on the inner continental shelf off the state of Espírito Santo (southeastern Brazil, Area 1- Guarapari Inner shelf -GUA and Area 2- Espirito Santo Bay - BES) and revealed bedforms much like those known as storm-generated bedforms. These bedforms are characterized by bands of fine sand deposited alternately over a coarse sand bottom, generating a deposit pattern of bands of fine sand intercalated with bands of coarse sand occurring between water depths of 25 to $30 \mathrm{~m}$ and five to eight $\mathrm{m}$ in GUA and ESB, respectively. In both areas, patches of coarse sand reveal the occurrence of wave-generated ripples, with crests that tend to be parallel to the coastline. The facies composition consists of very fine to fine muddy carbonate sands with siliciclastic fine gravel in GUA and coarse to medium sand with bioclastic gravel in BES. Thus, the influence of storm currents and waves in the formation and maintenance of these storm-generated bedforms is clear. However, the classification of the hydrodynamics and sediment transportation is required for estimating the formation, transportation and maintenance of these bedforms.

\section{R ESUMO}

Levantamentos sonográficos desenvolvidos em duas áreas da plataforma interna adjacente ao estado do Espírito Santo revelam formas de fundo cuja origem é fortemente relacionada a eventos de tempestades. Estas são caracterizadas por alternâncias de bandas de areias finas sobrepostas, de forma alternada, a um fundo de areias grossas, gerando manchas de areias grossas intercaladas abruptamente com faixas de areias finas a profundidades de 25-30 m para GUA e de 05-08 m para BES. Em ambas as áreas as faixas de areias grossas apresentam marcas de ondulação geradas por ondas com orientação levemente paralela a linha de costa. A sedimentologia de GUA é composta por areias finas a muito finas lamosas carbonáticas com cascalhos siliciclásticos e a de BES por areias grossas e médias com cascalhos biodetríticos. Desta forma, é clara a ação de correntes/ondas de tempestade no fundo marinho de GUA e de BES; porém, a classificação quanto ao comportamento hidrodinâmico e ao transporte de sedimento é necessária para as estimativas sobre a formação, transporte e manutenção das feições encontradas.

Descriptors: Storm events, Bedform, Tempestites, Inner Continental shelf, Brazil.

Descritores: Tempestades, Formas de fundo, Tempestitos, Plataforma continental, Brasil.

\section{INTRODUCTION}

The most important physical processes responsible for the transport and fluxes of sediment particles along and across the continental shelf are governed by tidally-induced currents, wave-orbital flows, wind-driven flows, buoyant plumes, density currents and internal waves (NITTROUER; WRIGHT, 1994). The shelf seabed morphology and associated morphological changes are the consequential combined effect of sediment erodibility, transportation and depositional processes. Sedimentary features (e.g. bedforms), found on the seabed, are developed as a result of such processes. In turn, their structural formation will be representative of the type of flow (transporting agent) and associated transport modes of the sedimentary material (transportable agent), acting during their formation and evolution. Bedform investigations are, usually, associated with observations of their morphology and sediment 
composition, which may indicate the type of flow that induced their development. However, during the evolutionary process of bedforms, a stratigraphic signature is produced, which will be associated, again, to the type of flow that induced the continuing evolution (migration) of the bedform.

On continental shelves dominated by microtidal patterns, wave action is the main determinant of sediment transportation and stormgenerated waves and currents are the main elements responsible for the large-scale re-mobilization and transportation of bottom sediments (GOFF et al., 2005). Among the storm-generated bedforms described thus far, there are "tabular sand patches" (KENYON, 1970), "hummocky megaripples" (SWIFT et al., 1983; AMOS et al., 1996) and "rippled scour depressions" (CACCHIONE et al., 1984), which were recently reclassified as "sorted bedforms" by Murray and Thieler (2004) due to the new hypotheses put forth by the authors regarding the maintenance and positioning of these bedforms.

All bedforms mentioned above have the same morphological/sedimentological characteristics: elongated bands/patches of coarse rippled sediments along with abrupt contact limits between these forms and fine sand domains. Storm-generated bedforms described thus far are found in areas of either symmetrical or asymmetrical deposits of fine sand intercalated by abrupt contact with elongated or patchy bands of coarse sediment with ripple marks. Reliefs in domains of fine and coarse sand in relation to the ocean bottom are also found within a range of approximately $<1 \mathrm{~m}$ and $<-1 \mathrm{~m}$, respectively. Despite these similarities, the geometry of the patches with regard to symmetry is a difference that reflects the divergences raised thus far regarding the hydrodynamics responsible for the formation, maintenance and spatial positioning of these bedforms (MURRAY; THIELER, 2004).

This paper presents a review of the main storm-generated bedforms described in the literature, highlighting their principal differences. Furthermore, two case studies are described that indicate the occurrence of storm-generated bedforms on the inner continental shelf off the state of Espírito Santo (southeastern Brazil).

\section{Bedforms}

\section{Sand Patches and Hummocky Megaripples}

The continental shelf is an environment with active sediment affected by the action of waves and longitudinal currents. The largest and most complex bedforms on the continental shelf originate in this type of environment (LOPES et al., 2003). Within this vast area, a number of authors have carried out data collections in order to characterize, understand and identify the sediment behavior and hydrodynamics that give rise to bedforms stemming from storm events.

Transverse bodies of sand were identified by Kenyon (1970) in side-scan sonar images in the northeastern Celtic sea, such as homogenous, lightcolored bodies standing out against a bed of dark tones that represent basal conglomerates from the Holocene transgression. These bodies (called "tabular sand patches" (Fig. 1A)) have lengths and heights in the range of $500 \mathrm{~m}$ and $2.0 \sim 4.0 \mathrm{~m}$, respectively, in either symmetrical or asymmetrical elongated crescent shapes oriented transversally to the tide currents. In a stratigraphic profile, these features consist of wellselected fine and medium-coarse sands, starting from a base of coarser sand and progressing gradually to finer sands toward the top. These forms are currently studied as developed from storm events due to this sediment grading and well-selected characteristic. In terms of formation, the hydrodynamics of a storm produces a coarse rippled bed by removing fine sediments. In other words, the base of the sand patches is formed by coarse rippled sediments that the energy of the waves was unable to suspend. As they occur on continental shelves dominated by weak tidal regime and fine sediments, these bedforms have considerable preservation potential. This occurs because a slight reduction in the intensity of the currents allows the depositing of mud (KENYON, 1970).

Due to this preservation capability, the tranverse sand patches found by Kenyon (1970) in the Celtic Sea may be made up of more than $50 \%$ biodetritus from carbonatic carapaces and skeletons of benthic organisms, which are able to develop in sites where sediment remains stable for a certain period of time. There may also be segregations in the composition of the seabed features, such as those found in the English Channel, where the composition of sand patches varies from purely siliciclastic bodies to carbonatic biodentritus bodies (BELDERSON et al., 1982).

Upon first contact, Swift et al. (1983) speculated that tempestites (deposits formed from the action of currents and storm waves) were the cause of the existence of sediments arranged in gradational layers with hummocky and cross stratification layers formed during winter storms in the North Atlantic. According to the author, the hummocky layers originated from hummocky cross stratifications, which, in turn, resulted from the generation and migration of a particular bedform - hummocky megaripples (AMOS et al., 1996).

Hummocky megaripples (HMRs) are bedforms composed of irregular, undulating, threedimensional features similar to small incurved mounts, with a low horizontal angle and large dimensions, capable of reaching various meters in length and a few 
decimeters in height (KLEINHANS et al., 2004). These deposits, which are formed by fine and medium-coarse sands, are found overlapping coarse and very coarse sand bottoms molded with asymmetrical ripple marks HMRs appear on the ocean floor during storms in environments with shallow waters, but there are as yet no conclusive hypotheses regarding the hydrodynamic conditions of their formation. Greenwood and Sherman (1986) suggest that hummocky megaripples are formed in the transition from rippled bedforms to the leveling of the sea floor due to strong storm currents. However, experimental tests carried out by Southard and Boguchwal (1990) demonstrate HMRs in the presence of strong, purely oscillatory flows (WALKER; JAMES, 1992). In a recent study, Li and Amos (1999) state that, as the strength of the storm diminishes, the suspended sediment is rapidly deposited, thereby modeling the hummocky megaripples by a combination of continual currents and oscillations of the long waves that are characteristic of a decline in storm energy. There are also studies carried out on the inner continental shelf of the North Sea (SWIFT, 1985; VAN DE MEENE et al., 1996) that credit the formation of hummocky megaripples to the dominant wave action with a slight overlapping of currents.

Observing hummocky megaripples at the structural level, the cross stratifications in the hummocky megaripples indicate a combined oscillatory flow action (CHEEL; LECKIE, 1992). Amos et al. (1996) examined HMRs on the continental shelf of Nova Scotia near Sable Island and used hydrodynamic data from recent storms, box cores
(AMOS et al., 1996) and side-scan sonograms to classify them as formed in the transition of laminar bottom flows to those of saltation/suspension over strongly undulating flows combined with constant, uniform currents.

\section{Rippled Scour Depressions and Sorted Bedforms}

Another characteristic feature of high energy events are the controversial "Rippled Scour Depressions" (RSDs). These bedforms (Fig. 2A) became known through papers by Cacchione et al. (1984), Cacchione et al. (1983) and Hunter et al. (1982), in which sonar data from the Coastal Ocean Dynamics Experiment (CODE), box cores, lowfrequency seismic data, tripods for collecting hydrodynamic data on the seabed and, consequently, sediment transport data were used. On the continental shelf near Bodega Bay (California) and the northeastern Bering Sea (Alaska), the authors investigated features made up of broad channels ( 100 to $200 \mathrm{~m})$ carved with a negative relief of $\sim 1 \mathrm{~m}$ in relation to the ocean floor, ranging in length from a few to many hundred kilometers, composed of coarse sediments in the form of large ripples oblique to the edges of the channel throughout their entire length and oriented transversally to the coast. These depressions are positioned alternately alongside other sediment structures, in extremely abrupt contact, made up of finer sandy sediments with a positive relief in relation to the seabed and having small ripples with a maximum of $5 \mathrm{~cm}$ in height and $30 \mathrm{~cm}$ of wavelength (CACCHIONE et al., 1984).

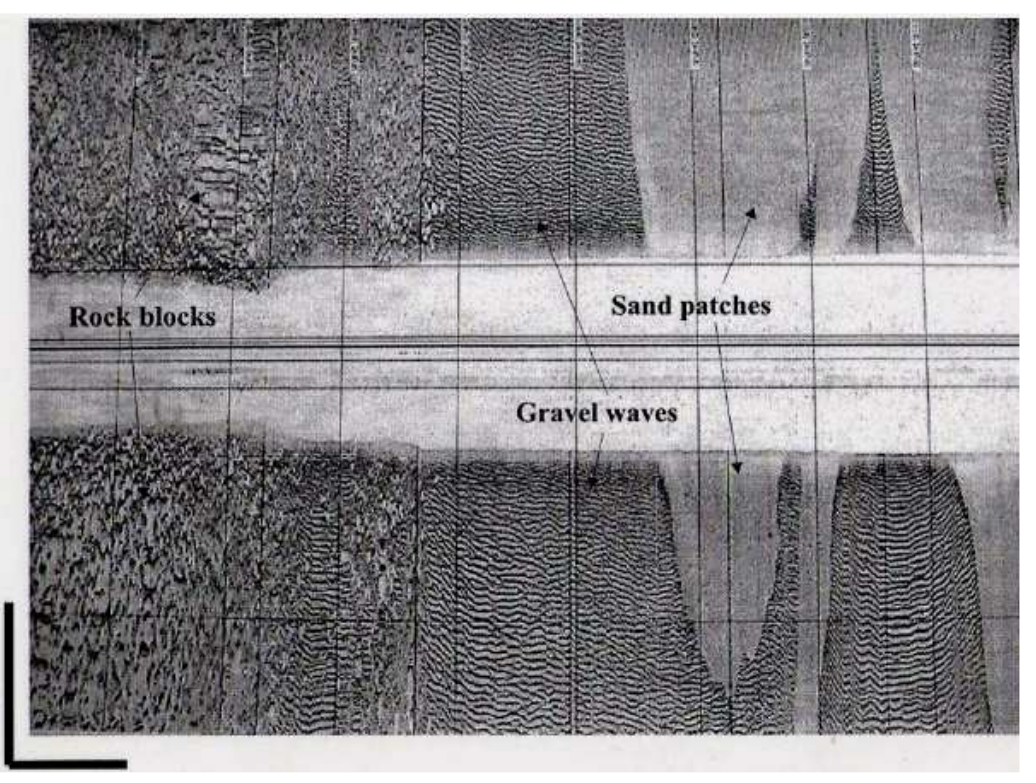

$65 m$
Fig. 1. Seabed image of Sand patches of Chesil Beach (Lyme Bay, southern UK) - dark gray tones represent coarse sediments with high acoustic reflection and light gray tones represent fine sediments of low acoustic reflection. 
According to Cacchione et al. (1984), the hydrodynamics related to these bedforms start with the principle of erosion of the seabed due to the return of an uneven flow through downwelling of the water from the coastal set up that occurs during the action of a storm. Associated to strong storm waves and obstacles (redirecting and intensifying bottom currents), this return current is thought to be sufficient for the formation of the eroded channels and ripple marks contained in the remaining coarse sediments. According to the authors, bed shear stress values match those necessary for the formation of welldeveloped ripple marks in coarse sediments. Suspended fine sediment is thought to be then deposited in adjacent areas with less turbulence, thereby forming deposits of fine sand.

However, studying the continental shelf dominated by storms off North Carolina, USA (Wrightsville Beach), Murray and Thieler (2004) raise contradictory hypotheses to those proposed by Cacchione et al. (1984) regarding the forming forces and maintenance of these RSDs. According to Murray and Thieler (2004), besides the notion that return flows through downwelling are insufficient when considering a large area of occupation by a rippled scour depression, the speculation of rocks as contributing toward the increase in flow intensity on the ocean floor has little basis, as their position is not obviously correspondent to the position of the

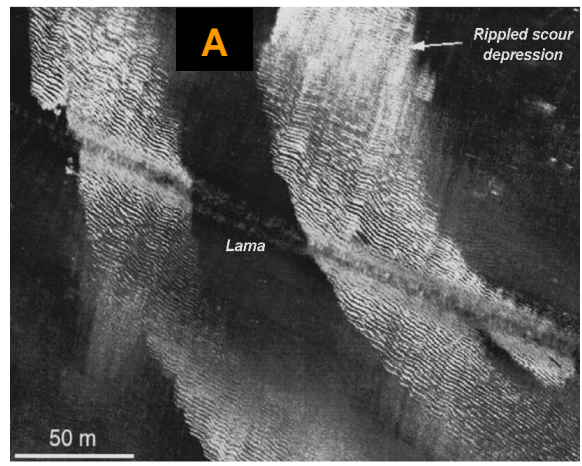

sediment features. Another point of disagreement is in the lack of explanation regarding the deposit sites of the fine sediment and its arrangement in relation to the carved out channels. Thus, the authors propose a new classification of storm-generated bedforms - "sorted bedforms" (SBs). This classification emerged following a reworking of the suppositions regarding the formation, maintenance and positioning of RSDs put forth by Cacchione (1984).

The new hypothesis regarding the origin of RSDs (or the hypothesis of the origin of sorted bedforms) involves the large wave-generated ripple marks in the coarse material. Wave movements that interact with these rippled elements generate bottom turbulence, which is intensified in comparison to that over other areas. This factor intensifies the bed shear stress, inhibiting the fine material from depositing on areas dominated by coarse sediment. Thus, the suspended sediment is carried by the currents and deposited in areas with finer sands. This hypothesis is raised as a self-organization of the seabed features, tending to accumulate fine sediment in areas of fine sediment and impeding its depositing on coarse sediment areas, regardless of the intensity of the prevailing hydrodynamic forces. Over time, small features interact with one another, forming patterns of large-scale, well-organized RSDs - "sorted bedforms" (Figs 2B and 2C) (MURRAY; THIELER, 2004; GOFF et al., 2005).

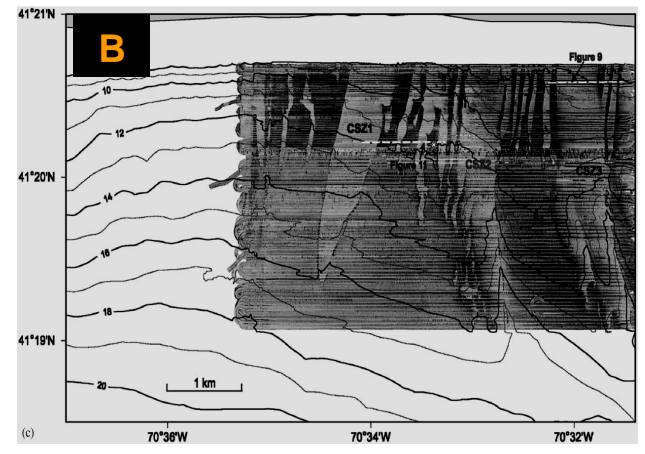

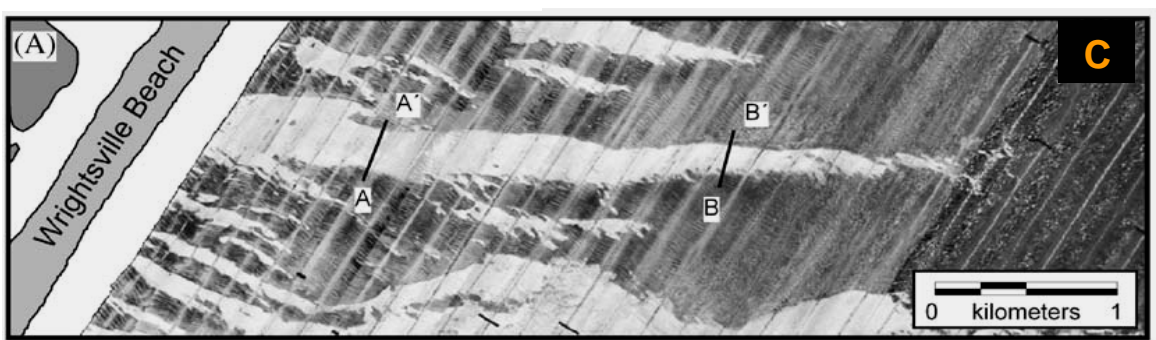

Fig. 2. A: Image of "Rippled Scour Depression" - dark gray tones represent coarse sediments with high acoustic reflection and light gray tones represent fine sediments of low acoustic reflection (EITTREIM et al., 2002). B and C: Mosaics composed of sonograms containing "Sorted bedforms" - dark gray tones represent coarse sediments and light gray tones represent fine sediments (GOFF et al., 2005; MURRAY AND THIELER, 2004). 
Unlike the RSDs described by Cacchione (1984), SBs have indications of the action of longitudinal currents in relation to the coastline, which are represented by gradual contact at one of the limits between fine and coarse sand domains. While Cacchione et al. (1984) states that the positioning of the band of coarser sediment is symmetric and centered in the low relief of the carved out channels, Murray and Thieler (2004) show that, in the case of $\mathrm{SBs}$, this band is asymmetric at the base/center of the slope, upstream from the longitudinal flow, between the fine sand and coarse sand domains. Added to the fact that the contact limit between the domains upstream from the longitudinal flow is gradual and has a positive relief, whereas the downstream contact limit is abrupt, there is a perceivable tendency toward the migration and maintenance of the SBs in the environment regardless of the environmental conditions.

However, it should be stressed that the selforganization and migration of the elongated features transversal to the coast made up of coarse material are not necessarily sorted bedforms to be developed in the

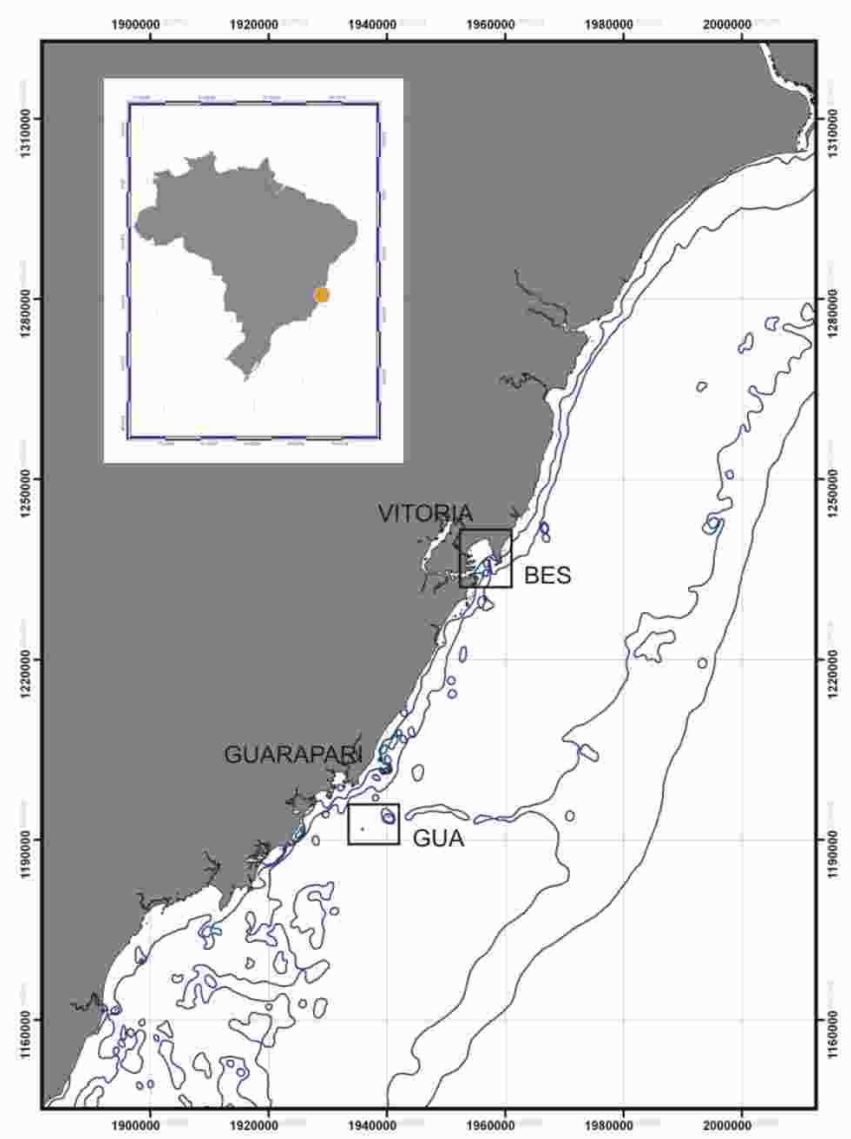

future. RSDs differ from SBs in the hypotheses of maintenance and spatial distribution, thereby stressing the capacity of the SBs for self-organization and migration and relegating the theories by Murray and Thieler (2004) regarding the formation of these bedforms to a secondary plane.

\section{Case Studies - Southeast BraziL}

The main interest of the present study is to show morphological and sedimentological evidence of bedforms and sediment deposits linked to high-energy events, demonstrating the occurrence of these features in southeastern Brazil. Two areas of the inner continental shelf off the state of Espírito Santo are presented (Fig. 3): Area 1 (inner continental shelf off the city of Guarapari - GUA); and Area 2 (Espírito Santo Bay - BES). These areas are wave-dominated in terms of prevailing hydrodynamics and exhibit the same bed morphological characteristics as those described by other authors when investigating stormgenerated deposits.

Fig. 3. Location of study areas: GUA Inner continental shelf of the city of Guarapari, B; BES - Espírito Santo Bay. Coordinates are in UTM, Zone 24S, with WGS84 Datum. 
Side-scan sonar surveys were performed along both areas during the winter of 2007. Seabed imaging was conducted using an Edgetech 4100 sidescan sonar with a $560 \mathrm{p}$ model digital processor, together with an Edgetech 272TD transducer (deep tow system that operates at $500 \mathrm{kHz}$ ), coupled to a Garmin GPS Map 76S. The data were later processed using the SonarWiz.Map software program (Cheasepeak Inc.) for the confection of the sonographic mosaics. Surface samples and short pushing-cores were collected for the definition of sediment composition associated with the reflection pattern found on the sonograms and sedimentological characterization of the deposits. The samples were processed to determine sediment grain size and carbonate content (Fig. 4). Bedform height was measured based on the seabed images collected by the side-scan sonar and sub-bottom seismic profiles.

Regarding the hydrodynamics, both areas have a microtidal pattern, with waves coming mainly from the NE - E and SE - E directions, the former being the dominant direction, and the latter being the storm-associated direction. The two wind systems in the region (NE - ENE and SE) govern the behavior of these waves. Higher-energy waves are associated with cold fronts from the south, whereas lower-energy waves from the northeastern sector are predominant throughout most of the year. Significant wave height ranges from 0.6 to $0.9 \mathrm{~m}$, reaching peaks of $1.5 \mathrm{~m}$ (ALBINO, 1999).

The area off Guarapari is an open shelf characterized by a transition from siliciclastic to biogenic sediments. In general, areas deeper than $20 \mathrm{~m}$ are dominated by biogenic sediments with approximately $70 \% \mathrm{CaCO}_{3}$. The sediments are coarsesized, ranging from sand to gravel (CETTO; BASTOS, 2006; CETTO; BASTOS, 2007) and mainly composed of bryozoan reef gravel and bioclastic sands. The Espírito Santo Bay is located about $50 \mathrm{~km}$ north from Guarapari, being a sheltered area as compared to Area 1. The bed is composed mainly of terrigenous sediments ranging from medium to fine sands (SW-NE direction) and mud, with coarse sands tending to concentrate in more central and outer areas of the bay. This pattern is associated with the incidence of waves, which generate a shadow area in the north-easternmost portion of the bay. Hence, it is important to note that the two areas studied are morphologically and sedimentologically distinct, although they are subject to similar meteorological and oceanographic forcing conditions.

\section{Inner Shelf - Guarapari}

Seabed imaging along GUA revealed the occurrence of storm-generated bedforms preferentially situated at depths of 20 to $30 \mathrm{~m}$. These were characterized as patches of sandy mud and muddy sands with no predominant spatial geometry, deposited on a bottom of coarse-rippled sands mostly oriented parallel to the coast. As the lines from the sonar survey are transversal to the coast, the features in some small areas were both parallel and transversal to the coastline, forming various sequences of light-colored, relatively symmetrical lines on the sonogram. Additionally, chaotic, asymmetrical, misshapen features with little or no orientation were found.

The sediments in areas of low backscattern of the acoustic signal were fine to very fine muddy bioclastic sands, corroborating the classic hypothesis followed by Belderson et al. (1982) and Kenyon (1970) for the formation of tabular sand patches. Likewise, sediments in areas of high acoustic reflection were related to medium to coarse lithobioclastic sands (Figs 4C and 4D). Two short pushing cores were collected to characterize the sedimentary deposits over the bedform. Core interpretation is shown in Figure 5.

The two cores collected over the deposit studied corroborate the concept of storm-generated bedforms. TP was collected in the low backscattern pattern and shows typical fining-upward gradational grain sequences. TR was collected in the coarserippled bed and is characterized by lithobioclastic coarse sands at the top, overlaying a fining-upward gradational sequence. It seems that the first $25 \mathrm{~cm}$ of TP is a typical tempestite, deposited over a coarse lag deposit, in this case, a shell hash. It's interesting to note that the fining-upward sequence in TR (sequence $\mathrm{B}, 19-59 \mathrm{~cm})$ is very similar in grain size and composition to the sequence B defined in TP. One could consider that sequence A from TR would be correlated with TP's sequence B, however their compositions are very distinct.

\section{Espírito Santo Bay}

The bedforms found in Espírito Santo Bay were concentrated preferentially in the northeastern portion of the bay at depths of 5 to $8 \mathrm{~m}$ (Fig. 6). These bedforms were characterized by long patches of muddy fine sand (low reflection pattern on the sonograms) intercalated in abrupt contract by patches of coarse and very coarse sand with associated ripple marks. The patches of fine sand were arranged in a chaotic manner, with a slight tendency toward being perpendicular to the coastline, and became increasingly less frequent toward the eastern side(?) of the bay until no longer present, giving way to muddy sand bottoms with no ornamentation. The sediments found in BES were made up of marls or very fine muddy silicibioclastic sands as well as coarse to very coarse siliciclastic sands in areas of high and low acoustic reflection, respectively. 

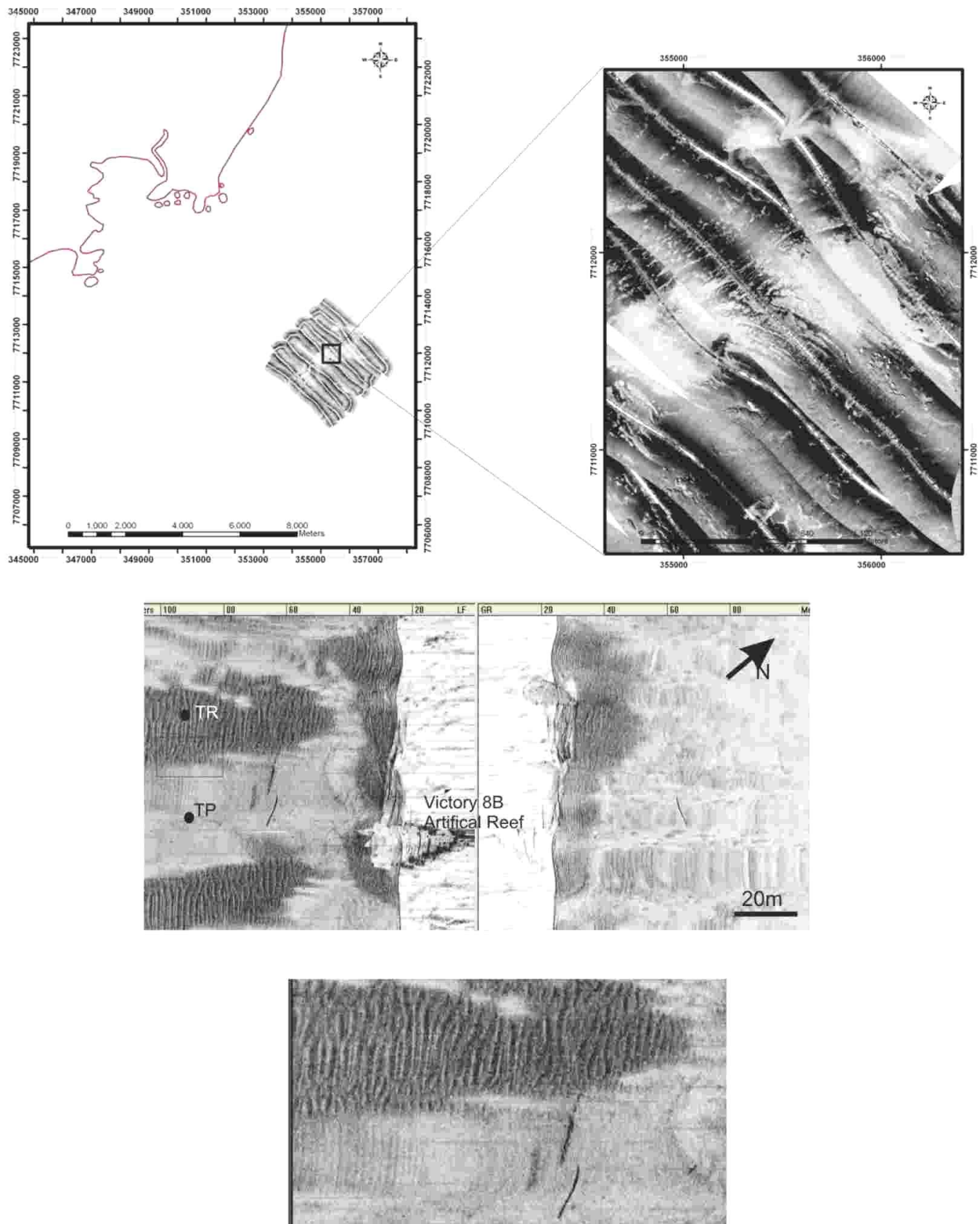

Fig. 4. Side-scan sonar images showing the occurrence of storm-generated bedforms. High-resolution $(500 \mathrm{kHz})$ sonograms (two images in the lower part) show detailed acoustic characteristics of these deposits. TR and TP represent the locations where two pushing-cores were collected. TR is a higher backscattern area representing a coarse rippled sand gravel bed, whilst TP is the low backscattern patterns representing very fine to muddy sands. 


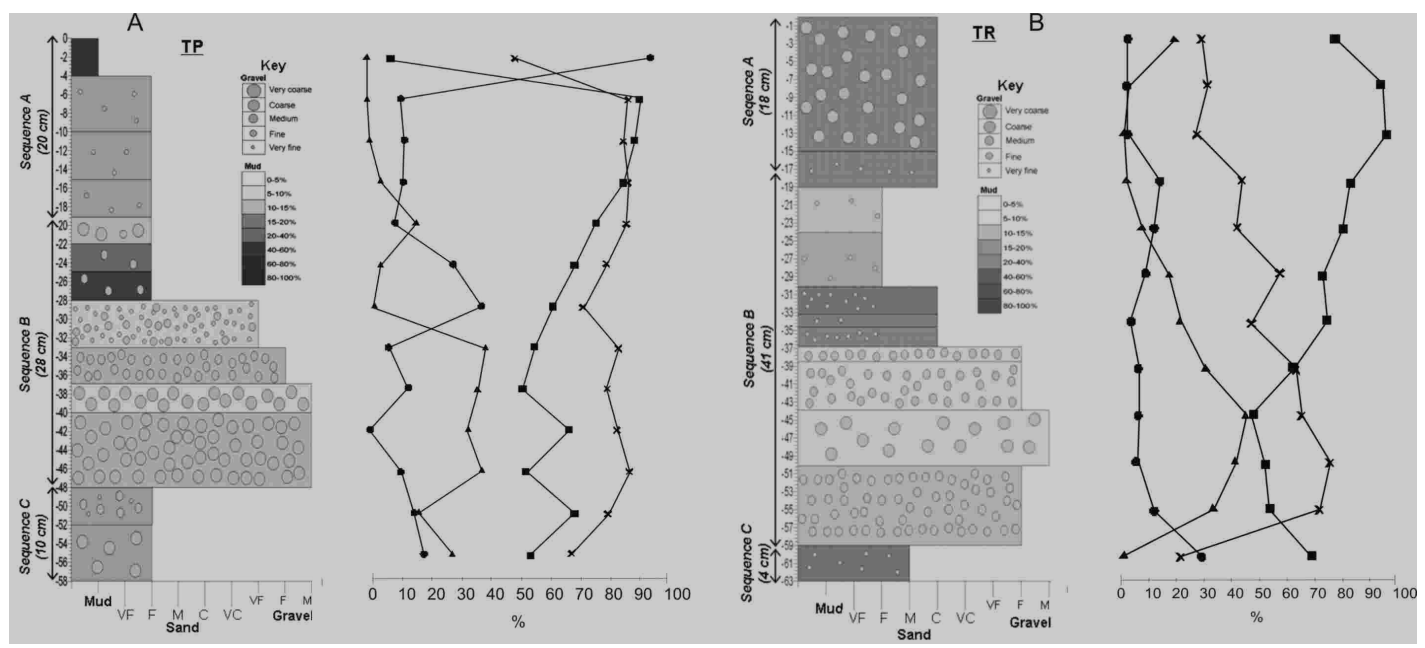

Fig. 5. Sedimentological results for the two short cores collected in GUA area. A) Core taken in the low backscattern patch; B) Core taken in the rippled bed (see Figure 4 for location). Legend: $\bullet-\mathrm{CaCO} 3$ content, $\square-$ Sand content, $\square$ - Mud content, $\square$ - Gravel content.

Core analysis revealed a typical storm sedimentary sequence characterized by a 20 to $30 \mathrm{~cm}$ thick fine sand deposit overlaying a coarse to very coarse sand layer. The tempestite is represented by sequence A in Figure 7A. Note that sequence A from T1 (ES1) is absent in T2 (ES2) and is overlaying a coarse sand facies (sequence B). In this case, the same coarse sand facies is observed in both cores, indicating that the tempestites are overlaying a coarse lag deposit.

In general, the results have pointed toward two domains of sedimentary facies presented in both case study areas: one with fine to very fine sands with mud and no obvious orientation in relation to the coastline as well as no surface bedforms; and the other with coarse sands with quite evident ripple marks, mostly oriented parallel to the coastline.

Hence, two sedimentary facies can be described: a rippled coarse sand facies and a featureless muddy sand facies. A detailed investigation of storm bedforms reveals that the rippled coarse sand bed is characterized by wave-generated ripples with heights ranging from 0.10 to $0.20 \mathrm{~m}$ and wavelengths between 0.80 to $1.4 \mathrm{~m}$. Ripple crests are straight to sinuous, but tend to be parallel to the coastline.

The greatest difference between the GUA and BES in sonographic terms is the scale of the bedforms and contact between the fine and coarse sand domains. Considering only the side-scan sonar scales, the features in the BES are well formed and larger, whereas, in particular sites of the GUA, the features were diffuse, with smaller, less clear limits. In the BES, the contact between the domains was more abrupt. The degree of intensification by the mobilization by the bottom currents may have caused this difference, as coarse remaining sediments are found on the bottom when there is greater concentration and strength of the bottom current.

The striking difference between the two areas studied is the sediment composition and the mean grain diameter. Although both areas had fine sediments in low backscattern areas and coarse sediments in high backscattern areas on the sonograms, the GUA sediments were comparatively coarser than the BES sediments. While fine sands are predominant in the GUA, there are very fine to marl sands found in the BES. There are very coarse to gravelly sands in the GUA and medium-coarse to very coarse sands in the BES in the dark areas on the sonograms. Accompanying this difference was the composition regarding the concentration of carbonates. The sediments found in low backscattern areas are bioclastic, but the proportion of carbonates found in the GUA was $40 \%$ greater than that found in the BES. The same was true for the high backscattern areas, in which the same difference in the concentration of carbonates was found.

\section{Discussion ANd Conclusions}

The bedforms found on the continental shelf of southeastern Brazil are likely linked to storm events, as they have the morphological characterization defined for this type of feature. The seabed with coarse rippled sands indicates a strong hydrodynamic event sufficient to suspend fine sediments and drag coarse bottom sediments, thereby forming ripples. This suspended fine sediment is then deposited in areas of lesser turbulence in the form of featureless patches of fine sand with no clear geometry. 


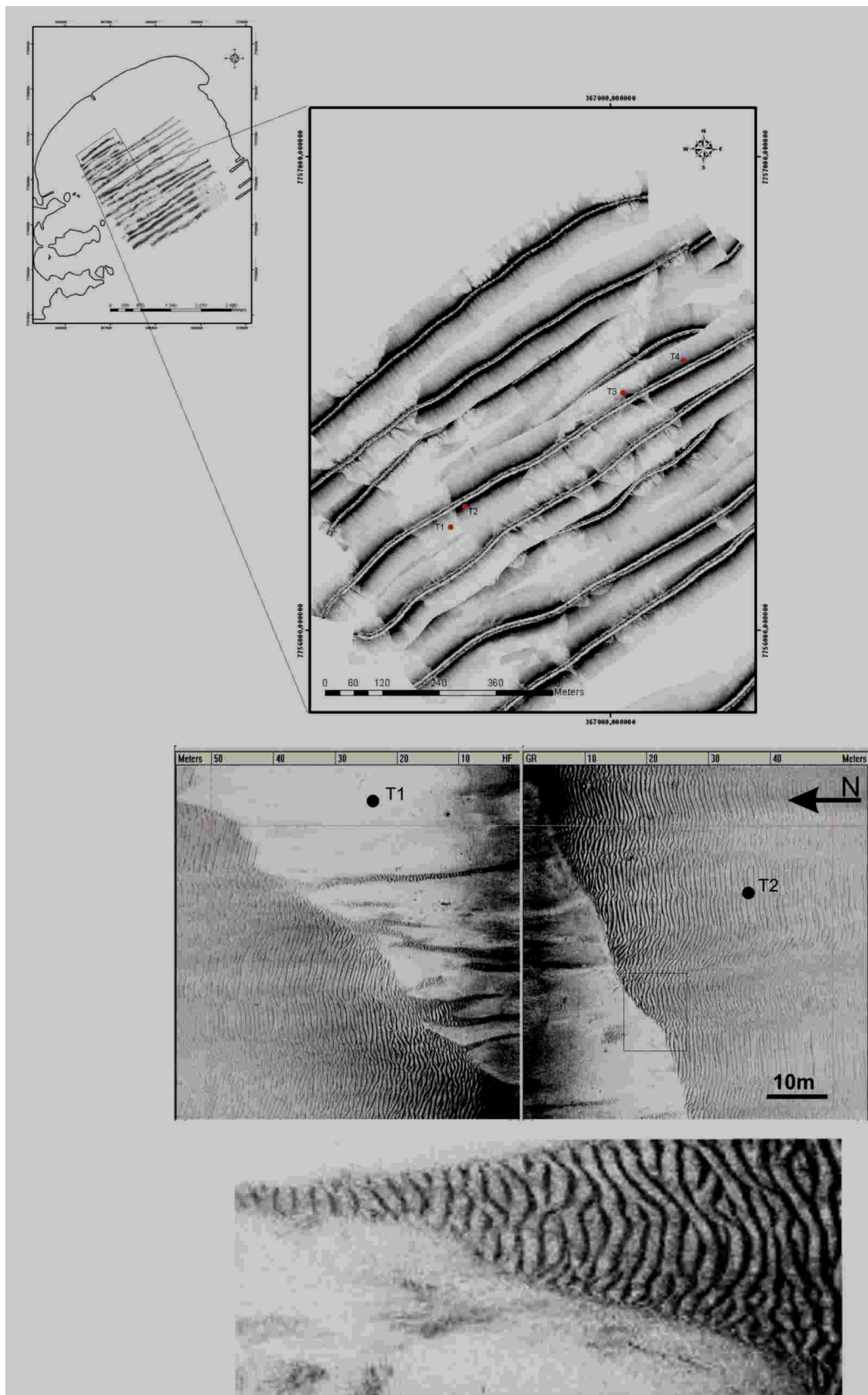

Fig. 6. Side-scan sonar images showing the occurrence of storm-generated bedforms over Espirito Santo Bay. High-resolution $(500 \mathrm{kHz})$ sonograms (two images in the lower part) show detailed acoustic characteristics of these deposits. T1 and T2 represent the locations where two pushing-cores were collected. T1 is the low backscattern patterns representing very fine to muddy sands, whilst T1 is a higher backscattern area representing a coarse rippled bed. 


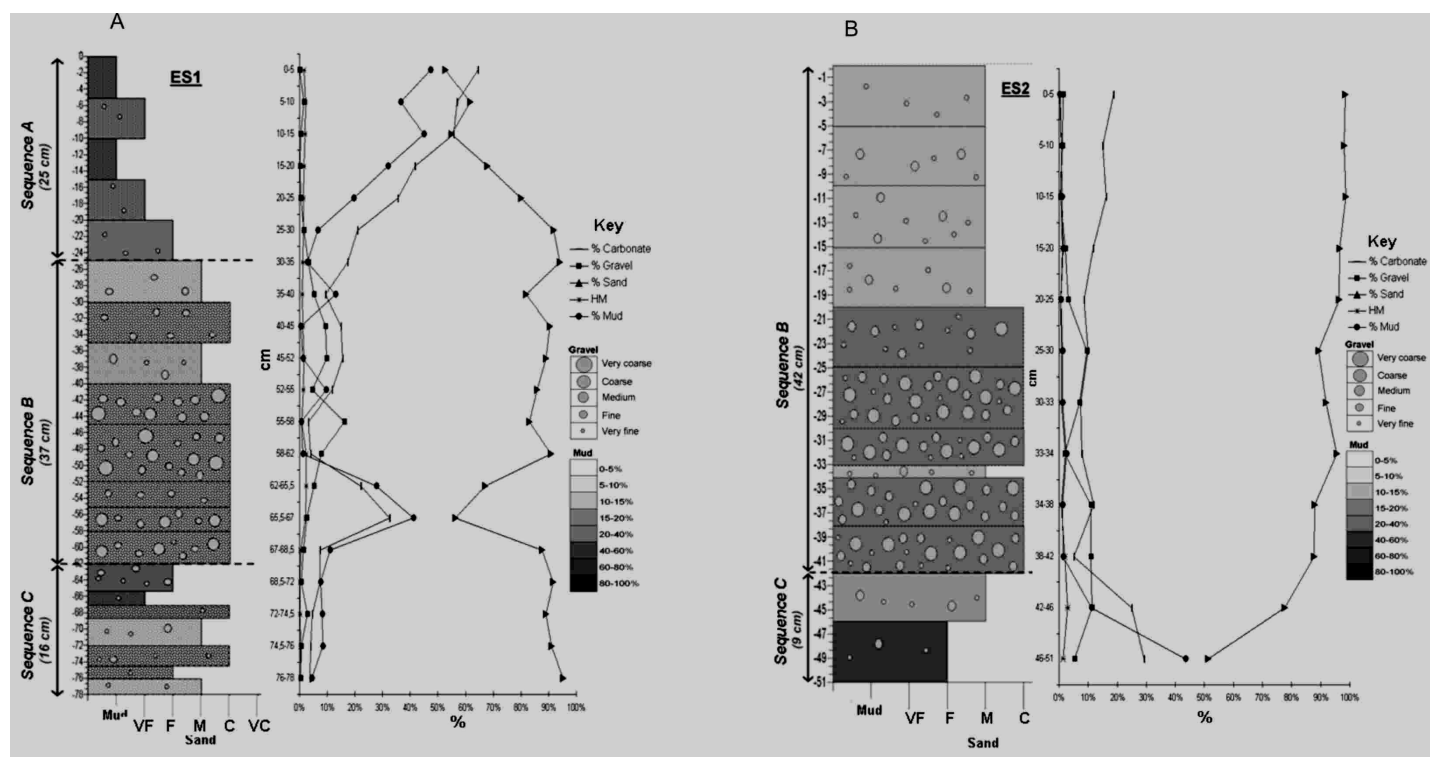

Fig. 7. Sedimentological results for the two short cores collected in BES area. A) Core taken in the low backscattern patch; B) Core taken in the rippled bed (see Figure 6 for location).

Analyzing only in terms of reflection patterns in the sonograms, morphology and positioning, the bedforms found in the two study areas were very similar to those originating from the remobilization of the sea floor due to storm events: patches of fine asymmetrical sands deposited over coarse rippled sand beds. Unlike those proposed by Cacchione et al. (1984) and Murray and Thieler (2004), the bedforms described here do not match the large-scale elongated, carved bedforms oblique to the coastline investigated by these authors. However, there are similarities to the features described by Kenyon (1970), who classifies the fine sand patches deposited on lag deposits with ripple marks with transversal orientation to the direction of the main current.

The table below (Table 1) shows the specific data on the morphological and hydrodynamic characteristics of sand patches, hummocky megaripples, rippled scour depressions and sorted bedforms, including height and length of the features and characteristics of the hydrodynamics linked to their formation. Due to the considerable variety of opinions and the increase in studies carried out on these bedforms derived from high-energy events, with characteristics of sand patches over coarse rippled beds, the classification of a recently discovered sediment deposit should be made with considerable caution. Besides the bedforms described above, Swift and Freeland (1978) state that bedforms on inner continental shelves in a number of areas within the eastern American shelf are relatively normal along the coastline, with low sandwaves spaced approximately 10 to $100 \mathrm{~m}$ apart, generated by coastal currents parallel to the coast and caused by the wind, but these bedforms do not support the argument of eroded channels of negative relief suggested thus far (CACCHIONE et al., 1984).

There is apparently no consensus regarding coarse sand bottoms being re-mobilized only during storm events that likely suspend, transport and deposit fine sands in locations of lesser turbulence. The greatest difference between all these bedforms is their spatial distribution and geometry, which likely reflects the direction of the transportation of sediments in the area investigated. On the other hand, it seems that this sand patch pattern observed in sidescan images can be related to wave-dominated shelves, or at least, associated with storm-induced bedforms/facies.

Finally, the results presented for the two case study areas have revealed the occurrence of storminduced sedimentary facies. Two domains of sedimentary facies are described: a featureless muddy sand sheet and coarse rippled sand facies. Short cores exposed a typical storm sedimentary sequence over the muddy sand sheet, characterized by a 20 to $30 \mathrm{~cm}$ thick tempestite deposit overlaying a coarse to very coarse rippled sand layer. 
Table 1. Morphological and hydrodynamic characteristics of the bedforms of greater interest; H: Height of fine sand domain and channel depth of coarse sand domain (when present); L: Length; W: Width; D: Depth of water column (Kenyon, 1970; Amos et al., 1996; Cacchione et al., 1984; Murray \& Thieler, 2004).

\begin{tabular}{|c|c|c|c|c|c|c|}
\hline BEDFORM & $\begin{array}{c}\text { CURRENT } \\
\text { (Bottom) }\end{array}$ & $\begin{array}{c}\text { HYDRODYNAMIC } \\
\text { DOMAIN }\end{array}$ & $\begin{array}{c}\text { H/L/W/D } \\
(\mathbf{m})\end{array}$ & $\begin{array}{l}\text { ORIENTATION } \\
\text { (Coast) }\end{array}$ & $\begin{array}{l}\text { ORIENTATIO } \\
\text { N "Ripples" }\end{array}$ & SITE \\
\hline Sand Patch & $<0.5 \mathrm{~m} / \mathrm{s}$ & $\begin{array}{l}\text { Weak tide + wave } \\
\text { oscillation }\end{array}$ & $\begin{array}{c}\sim 2.0 \\
500 \\
\infty \\
\infty\end{array}$ & $\begin{array}{l}\text { Both domains: } \\
\text { Transversal }\end{array}$ & $\begin{array}{c}\text { Transversal to the } \\
\text { tide flow }\end{array}$ & $\begin{array}{c}\text { Kenyon (1970), } \\
\text { Celtic Sea } \\
\text { Case Studies } \\
\text { Presented } \\
\text { Here }\end{array}$ \\
\hline$H M R$ & $\begin{array}{l}0.3 \text { to } 0.1 \\
\mathrm{~m} / \mathrm{s}\end{array}$ & $\begin{array}{l}\text { Dissipative storm } \\
\text { wave + uniform } \\
\text { bottom current }\end{array}$ & $\begin{array}{c}\sim 0.2 \\
30-40 \\
\infty \\
05-30\end{array}$ & Undefined & $\begin{array}{l}\text { Fine domain: } 3- \\
\text { dimensional } \\
\text { Coarse domain: } \\
\text { Transversal to the } \\
\text { flow and storm } \\
\text { waves }\end{array}$ & $\begin{array}{l}\text { Swift et al. } \\
\text { (1983), } \\
\text { North Atlantic } \\
\text { Amos et al. } \\
\text { (1996), Nova } \\
\text { Scotia }\end{array}$ \\
\hline$R S D$ & $\begin{array}{c}0.4 \text { to } 0.2 \\
\mathrm{~m} / \mathrm{s}\end{array}$ & Storm wave & $\begin{array}{c}<1.0<-1.0 \\
100-1000 \\
100-200 \\
>45\end{array}$ & $\begin{array}{l}\text { Both domains: } \\
\text { Transversal }\end{array}$ & $\begin{array}{l}\text { Transversal to the } \\
\text { flow of the } \\
\text { downwelling }\end{array}$ & $\begin{array}{c}\text { Cacchione et al. } \\
\text { (1984), Bodega } \\
\text { Bay Hunter et } \\
\text { al. (1982), } \\
\text { Bering Sea }\end{array}$ \\
\hline$S B$ & $\begin{array}{l}0.4 \text { to } 0.2 \\
\mathrm{~m} / \mathrm{s}\end{array}$ & $\begin{array}{c}\text { Storm wave }+ \\
\text { longitudinal current }\end{array}$ & $\begin{array}{c}<2.0<-1.0 \\
\sim 500 \\
>500 \\
>10\end{array}$ & $\begin{array}{l}\text { Both domains: } \\
\text { Transversal }\end{array}$ & Transversal & $\begin{array}{c}\text { Murray and } \\
\text { Thieler (2004), } \\
\text { Wrightsville } \\
\text { Beach }\end{array}$ \\
\hline $\begin{array}{c}\text { GUA } \\
\text { Bedform }\end{array}$ & $0,5 \mathrm{~m} / \mathrm{s}$ & $\begin{array}{l}\text { Weak tide }+ \text { Storm } \\
\text { wave }\end{array}$ & $\begin{array}{c}\infty \\
\infty \\
\infty \\
20-30\end{array}$ & $\begin{array}{l}\text { Parallel and } \\
\text { transversal }\end{array}$ & $\begin{array}{l}\text { Parallel to the } \\
\text { coast }\end{array}$ & $\begin{array}{c}\text { Southern } \\
\text { Brazil, } \\
\text { Guarapari inner } \\
\text { shelf - GUA }\end{array}$ \\
\hline $\begin{array}{c}\text { BES } \\
\text { Bedform }\end{array}$ & $0,1 \mathrm{~m} / \mathrm{s}$ & $\begin{array}{c}\text { Weak tide }+ \text { storm } \\
\text { wave }+ \text { longitudinal } \\
\text { current }\end{array}$ & $\begin{array}{c}\infty \\
\infty \\
\infty \\
05-08\end{array}$ & Transversal & $\begin{array}{l}\text { Parallel to the } \\
\text { coast }\end{array}$ & $\begin{array}{c}\text { Souther Brazil, } \\
\text { Espírito Santo } \\
\text { Bay - BES }\end{array}$ \\
\hline
\end{tabular}

\section{ACKNOWLEDGEMENTS}

This study underwent various stages of development, which included structural and institutional support from the Universidade Federal do Espírito Santo and Universidade Federal Fluminense, including bibliographic and academic support provided by professionals working in both institutions. Financial and field collection support was obtained within three distinct sources: IEMA-UFES Victory-8B Environmental Monitoring Programme, COPESPetrobrás and FACITEC (Fundo Municipal de Ciência e Tecnologia de Vitória). The first author is supported by a scholarship from Agência Nacional do Petróleo (ANP). Acknowledgment is due to those who contributed in the field during the sonar and core data collection and those in the laboratories during the processing of the sonographic and sedimentological data.

\section{REFERENCES}

ALBINO, J. Processos de sedimentação atual e morfodinâmica das praias de Bicanga a Povoação,
ES. 1999.182 p. Tese de Doutorado, Programa de PósGraduação Geologia Sedimentar. São Paulo: USP, 1999. AMOS, C. L.; LI, M. Z.; CHOUNG, K. -S. Storm-generated, hummocky stratification on the outer-Scotian Shelf. Geo-Marine Letts, v. 16, p. 85-94, 1996.

BELDERSON, R. H.; JOHNSON, M. A.; KENYON, N. H. In: STRIDE, A H. (Ed.). Offshore tide sands: processes and deposits. London: Chapman and Hall, 1982. cap. 3, p. 27-57.

CACCHIONE, D. A.; DRAKE, D. E.; GRANT, W. D.; WILIAMS, A. J.; TATE, G. B. Variability of sea-floor roughness within the coastal ocean dynamics experiment (CODE) region. Woods Hole oceanogr. Inst., Tech. Rept., n. 25-83, 183, 44 p., 1983.

CACCHIONE, D. A.; GRANT, W. D.; TATE, G. B. Rippled scour depressions on the inner continental shelf off central California. J. sediment. Petrology. v. 54, p. 1280-1291, 1984.

CETTO, P. H.; BASTOS, A. C. Padrões de reflexão sonográficos associados a depósitos sedimentares biodetríticos em um trecho da plataforma continental interna ao largo de Guarapari - ES. In: SIMPÓSIO BRASILEIRO DE GEOFÍSICA (SBGF), 2006, Natal, RN. Anais ... 2006. CD-ROM

CETTO, P. H.; BASTOS, A. C. Faciologia de sedimentos carbonáticos biogênicos, plataforma continental interna de Guarapari, ES - Brasil. In: Congresso LatinoAmericano de Ciências do mar - COLACMAR, 12. Florianópolis, SC, 2007. Anais ... 2007. CD-ROM. 
CHEEL, R. J.; LECKIE, D. A. Coarse-grained storm beds of the Upper Cretaceous Chungo Member (Wapiabi Formation), southern Alberta, Canada: J. sedim. Petrology, v. 62, p. 933-945, 1992.

EITTREM, S. L.; ANIMA, R. J.; STEVENSON, A. J. Seafloor geology of the Monterey Bay area continental shelf. Mar. Geol., v. 181, p. 3-34, 2002.

GOFF, J. A.; MAYER, L. A.; TRAYKOVSKI, P.; BUYNEVICH, I.; WILKENS, R.; RAYMOND, R.; GLANG, G.; EVANS, R. L.; OLSON, H.; JENKINS, C. Detailed investigation of sorted bedforms, or "rippled scour depressions", within the Martha's Vineyard Coastal Observatory, Massachusetts. Continent. Shelf Res., v. 25, p. 461-484, 2005.

GREENWOOD, B.; SHERMAN, D. J. Hummocky crossstratification in the surf zone: flow parameters and bedding genesis. Sedimentology, v. 33, p. 33-45, 1986.

HUNTER, R. E.; THORN, D. R.; SWISHER, M. L. Depositional and erosional features of the inner shelf, northeastern Bering Sea. Geologie Mijnb., v. 61, p. 4962, 1982.

KENYON, N. H. The origin of some transverse sand patches in the Celtic Sea. Geologic. Magaz., v. 102, p. 389-394, 1970.

KLEINHANS, M. G.; PASSCHIER, S.; VAN DIJK, T. A. G. P. The origin of megaripples, long wave ripples and Hummocky Cross-Stratification in the North Sea in mixed flows, p. 142-151. In: HULSCHER, S.; GARLAN, T.; IDIER, D. WORKSHOP INTERNATIONAL, MARINE SANDWAVE AND RIVER DUNE DYNAMICS, 2, University of Twente, Netherlands, 2004. 352 p.

LI, M. Z.; AMOS, C. L. Sheet flow and large wave ripples under combined waves and currents: Field observations, model predictions and effects on boundary layer dynamics. Continent. Shelf Research. v. 19, p. 637663, 1999.

LOPES, A. L. M.; SILVA, C. G.; DIAS, G. T. M. Caracterização sonográfica das feições arenosas de fundo da plataforma continental interna e média a sul da Bacia de Campos. In: CONGRESSO INTERNACIONAL DA SOCIEDADE BRASILEIRA DE GEOFÍSICA, 8., 2003. Anais ... 2003.
MURRAY, A. B.; THIELER, E. R. A new hypothesis for the formation of large-scale inner-shelf sediment sorting and 'rippled scour depressions'. Continent. Shelf Res, v. 24, p. 295-315, 2004.

NITTROUER, C. A.; WRIGHT, L. D. Transport of particles across continental shelves. Revs Geophys., v. 32, n. 1, p. 85-113, 1994.

SOUTHARD, J. B.; BOGUCHWAL, A. Bed configurations in steady unidirectional water flows. Part 2. Synthesis of flume data. J. sedim. Petrology, v. 60, n. 5, p. 658-679, 1990.

SWIFT, D. J. P. Response of the shelf floor to flow. In: TILLMAN, R. W.; SWIFT, D. J. P.; WALKER, R. G. (Ed.). Shelf sands and sandstone reservoirs. SEPM Short Course, v. 13, p. 135-241, 1985.

SWIFT, D. J. P.; FREELAND, G. L. Sand waves and current lineation on the inner shelf, Middle Atlantic Bight of North America. Mar. Geol., v. 48, p. 1257-1266, 1978.

SWIFT, D. J. P.; FIGUEIREDO, A. G.; FREELAND, G. L.; OERTEL, G. F. Hummocky cross-stratification and megaripples: A geological double-standard?, J. Sedim. Petrology, v. 53, p. 1295-1317, 1982.

VAN DE MEENE, J. W. H.; BOERSMA, J. R.; TERWINDT, J. H. J. Sedimentary structures of combined flow deposits from the shoreface connected ridges along the central Dutch coast. Mar. Geol., v. 131, p. $151-175,1996$.

WALKER, R. G.; JAMES, N. P. Facies Models: Response to sea level change. Canada: GEOText1, 1992. 454 p. 